Exp. Anim. 41(4), 481-489, 1992

\title{
Effect of Sex Hormones on the Onset of Diabetic Syndrome in WBN/Kob Rats
}

\author{
Tadashi SAEGUSA, Hiroshi KON*, Minoru TSUCHITANI**, \\ and Isao NARAMA*** \\ Toxicology Research Laboratories, Fujisawa Pharmaceutical Co., Ltd., 2-1 Kashima, \\ Yodogawa-ku, Osaka-shi, Osaka 532, *Naruto Research Laboratories, Otsuka \\ Pharmaceutical Factory, Inc., 115 Tateiwa, Muya, Naruto-shi, Tokushima \\ 772, ${ }^{* *}$ Mitubishikasei Institute of Toxicological and Environmental \\ Sciences, 14 Sunayama, Hasakimachi, Ibaraki 314-02, and ${ }^{* * *}$ Research \\ Institute of Drug Safety, Setsunan University, 45-1 \\ Nagaotoge-cho, Hirakata-shi, Osaka 573-01, Japan
}

(Received 21 April 1992/Accepted 19 June 1992)

The effects of sex hormone on diabetic conditions were investigated in WBN/Kob strain rats, i. e., castrated or spayed, hormone-treated, and non-treated rats. The effects of sex hormone on glycosuria, body-weight change, glucose tolerance and histopathology of the pancreas were compared among these animals. There were no abnormal changes in these parameters in the non-treated females and estrogentreated males. The glycosuria began to be observed from the age of about 30 weeks in the non-treated group and from the age of 52 weeks in the castrated group. In the female animals, this symptom began to appear from the age of 55 weeks in the testosterone-treated group and from the age of 72 weeks in the spayed group. Before the onset of the diabetic symptoms, glucose tolerance was impaired in these animals. Body weights of the castrated and estrogen-treated males were lower than that of the non-treated males, especially in the estrogen-treated males. Those of the spayed and testosterone-treated females were much heavier than that of the nontreated females. Testosterone treatment accelerated body-weight gain in the spayed female animals. Histopathological examination of the pancreas revealed atrophy of the aciner tissue and atrophy and disappearance of the islet cells similar to those of the non-treated WBN/Kob male rats in the castrated males, spayed females and testosterone-treated females. However, these changes were not observed in the non-treated females or estrogen-treated males. These findings suggest that female hormone suppressed the onset of hyperglycemia along with glycosuria and male hormone accelerates the onset of hyperglycemia in the WBN/Kob rats. - KEY WORDS : diabetes, estrogen, gonadectomy, testosterone, WBN/Kob rat

\author{
WBN/Kobラットの糖尿発症に及ぼす \\ 性ホルモンの影響 \\ 三枝 雅·昆 弘志*.土谷 稔**.奈良間 功*** \\ 藤沢薬品工業株式会社安全性研究所 \\ *株式会社大塚製薬工場鳴門研究所 \\ **株式会社三菱化成安全科学研究所 \\ ***摂南大学薬物安全科学研究所
}


WBN/Kob ラットにおける尿糖排泄を伴ら糖尿病お よびそれに伴う種々の合併症（白内障, 腎臓における Armanni-Ebstein 病変, 系球体病変ならびに末梢神 経における神経症等) は雄だけに認められ，その発症に 対する明らかな性差が存在する $[3,11,15,16]$ 。

しかし，著者らは本系統雌ラットに拉いても，その卯 巣を摘出することにより全例に雄ラットと同質の膵臓の 外分泌腺組織の萎樎および脺島の萎縮・消失が認められ ること, 加えて, その一部例に多飲·多尿, 白内障, 尿 糖排泄および高血糖状態などが発現することを指摘し， これらのことから WBN/Kob ラットの糖尿病の発症に は雙性ホルモンが抑制的に関与していることを推察した [7]。本報告では, WBN/Kob 䊒雄ラットの性腺摘出に 加えて雄に雙性ホルモン, 倠に雄性ホルモンを投与し, 糖尿病態発症に対する性ホルモンの影響を検討した。

\section{材料および方法}

1. 供試動物：実験にはWBN/Kob ラットの倠雄計 127匹を使用した。

2. 飼育条件：実験期間を通してて動物を温度 $24 \pm 2$ ${ }^{\circ} \mathrm{C}$, 湿度 $50 \pm 10 \%$, 換気回数約 16 回/時, 8 時から 20 時 までの 12時間照明下の Barrier 施設内で網底・尿㿼付 きのステンレス性ケージ（幅 $37 \mathrm{~cm} \times$ 奥行 $47 \mathrm{~cm} \times$ 高さ $19 \mathrm{~cm} ）$ に 1 ないし 5 匹ずつ飼育し，放射線照射隇菌さ れた固形飼料（株式会社船橋農場製 FR-2）および塩素 減菌された井水を自由に摂取させた。

3. 実験群の構成

1）雄ラット実験群：無処置対照群，精巣摘出群およ び精巣摘出に加えて Estradiol benzoate を投与した群 （以下，エストロジェン投与群）の 3 群を設定し，各群 にそれぞれ15，9および29匹の動物を配した。なお，去 勢は 3 週龄の時点においてケタラール麻酔下で腹部を剃 毛後に陰茎前方の腹部正中腺を切開して精巣と精巣上体 を摘出することによって実施した。

また, Estradiol benzoate ( $\beta$-estradiol3-benzoate SIGMA Chemical Company 製 Lot No. 63 F-0541) は corn oil に溶解し， $50.0 \mu \mathrm{g} / \mathrm{head} /$ week 4 週龄か 560週龄にかけて1 週間に一度の割合でェストロジェン 投与群の背部皮下に投与した。これら各群の全例を無処 置対照群では69週龄, 精巣摘出群では52週龄およびェス トロジェン投与群では75週龄まで飼育した。

2）榫ラット実験群: 無処置対照群, 卵巣摘出群およ び卵巣摘出に加えて Testosterone propionate を投与 した群（以下，テストステロン投与群）の 3 群を設定
し，各群にそれぞれ18，37および19匹を配した。なお， 卵巣摘出は 3 週龄の時点においてケタラール麻醉下で背 部を剃毛後に背部正中線の皮虚および左右背筋を切開し て卵巣を割去した。

また, Testosterone propionate (SIGMA Chemical Company 製 Lot No. 114 F-04301）は corn oil に溶解 し, $3.0 \mathrm{mg} / \mathrm{head} /$ week を 4 週龄から60週龄にか计て 1 週間に一度テストステロン投与群の背部皮下に投与し た。これら各群の全例を無処置対照群および卵巣摘出群 では88週龄，テストステロン投与群では75週龄まで飼育 した。

4. 検查項目

1）体重および尿糖の測定：実験期間中，全例の体重 を週 1 回測定し，定期的に全例の新鮮尿を採取して尿糖 検查紙（Eli-Lilly 社製 Tes-Tape ß）により尿糖の発 現の有無を調べた。

2）耐糖能検査 : 倠雄各群の 5 例について 30 扎よび 60 週龄の時点でブドウ糖負荷による耐糖能検査を実施し た。耐糖能検査に際しては，検査前日より約16時間の絶 食を施し，無麻酔下で眼窩静脈叢より負荷前の採血を行 ったのち $40 \%$ glucose 水溶液を $2 \mathrm{ml} / \mathrm{kg}$ の割合で腹腔 内投与し, 負荷前, 負荷後 30 分, 60 分および 120 分の血 糖値をデキストロ・メーター（マイルス・三共株式会社 製）を用いて測定した。

なお，用いた機器の特性により，血糖の定量は $400 \mathrm{mg}$ $/ \mathrm{dl}$ が上限であったので，それ以上の值はすべて $400 \mathrm{mg}$ $/ \mathrm{dl}$ として処理した。

3）血清生化学的検査：雌雄各群の全例をそれぞれの 計画屠殺時の前日より約16時間絶食させたのち, エーテ ル麻酔下で腹部大動脈より採血し，遠心分離により得ら れた血清について，グルコース ( Glu : 酵素法), トラン スアミラーゼ (GOT \& GPT. : karmen 変法), アルカ リ性ホスファターゼ (ALP : Kind-King 变法)，トリ グリセライド (TG : 酵素法), 総コレステロール (TC hol : 酵素法), 総蛋白 (TP : Biuret 法) クレアチニン (Creat: Jaffe 変法), アルブミンおよびアルブミン・ グロブリン比 (Alb \& A/G : BCG 法), 総ビリルビン (TBil : Michaelsson-Heirwegh 変法) およびカル シウム（S-Ca：o-CPC 法）を自動分析装置（Hitachi Automatic Analyzer 706 D) により測定した。

4）病理組織学的検査 : 血清生化学的検査で採血され たすべての個体をエーテル麻酔下で放血殺した後，膵臓 を10\%ホルマリン液で固定し，常法に従ってパラフィン 包埋, 薄切後, Hematoxylin-Eosin 染色を施して鏡検 した。 


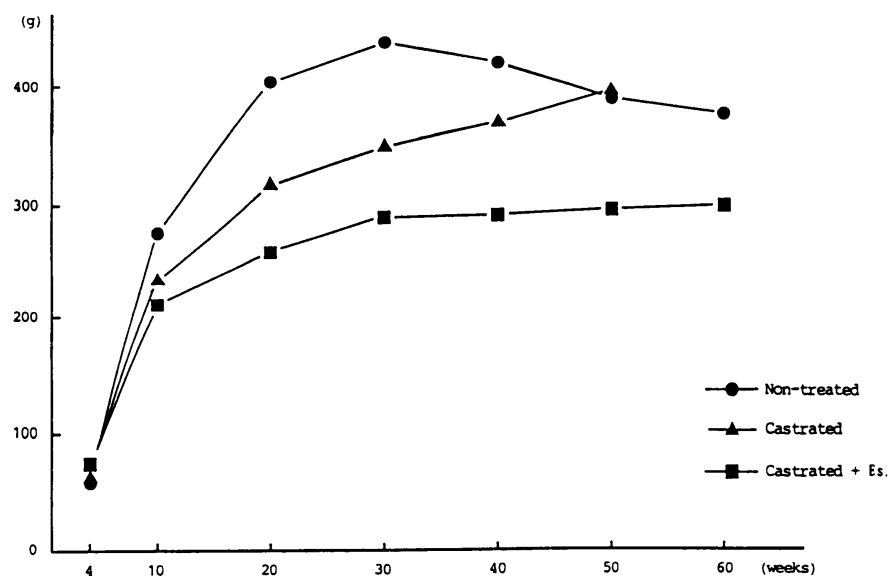

Fig. 1. Effect of castration and estradiol benzoate on body weight changes in male WBN/Kob rats
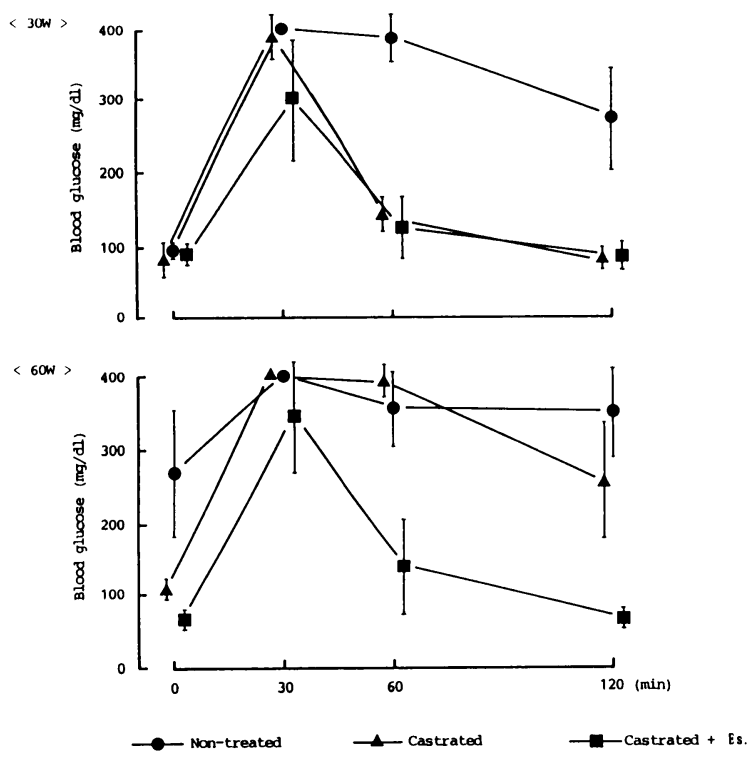

Fig. 2. Effect of castration and estradiol benzoate on GTT levels in male WBN/Kob rats

\section{成 績}

1）雄ラット実験群

臨床症状 : 各群とも30週龄までは一般状態に変化は認
められなかった。しかしながら, 無処置対照群では30週

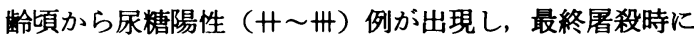
あたる69週龄までの累積尿梧陽性率は100\%であった。 当該群の尿糖陽性例は尿糖出現に一致して多飲・多尿に なり，その後削瘦，軟便の排泄および白内障などを呈し た。しかし，精巣摘出群およびェストロジェン投与群で はそれぞれ52週龄および75週龄に至るまで尿糖排泄は 1 例にも認められなかった。

体重の推移：各群の体重の推移を Fig. 1 に示した。 エストロジェン投与群の体重は10週龄以降顕著な增加 抑制を示し，10週龄から60週龄にかけて無処置対照群と 比べて有意な低値（約20\%ないし35\%の低値）で推移し た。一方，精巣摘出群の体重は10週龄から40週龄までの 他の 2 群のほぼ中間の値で推移した。

ブドウ糖負荷による耐糖能検査 : $30 お よ ひ ゙ 60$ 週龄にお。 ける各群の糖負荷後の血糖曲線を Fig. 2 に示した。

30週龄では無処置対照群の血糖曲線はすでに糖尿病型 を示したのに対し, 他の 2 群の血糖曲線はいずれる正常 型であった。60週龄においては無処置対照群に加えて精 巣摘出群の血糖曲線も糖尿病型を示したが，エストロジ ェン投与群の血糖曲線は依然として正常型であった。

血清生化学的検査 : 各群の血糖をはじめとする血清生 化学的検查を Table 1 亿示した。

屠殺時の血糖値は無処置対照群では395.4 4 93. 31 (211 $\sim 516 \mathrm{mg} / \mathrm{dl}$ ) で明らかに高血糖であったのに対して精 巣摘出群では $235.2 \pm 26.54(193 \sim 274 \mathrm{mg} / \mathrm{dl})$ であり, 稍程度は軽减する傾向にあったが同様に高血糖と判定さ れる血糖值を示した。これに対してェストロジェン投与 
Table 1. Effect of castration and estradiol benzoate on serum biochemistry in male WBN/Kob rats

\begin{tabular}{|c|c|c|c|c|c|c|c|c|c|}
\hline \multicolumn{2}{|c|}{ Items / Group } & \multicolumn{3}{|c|}{ Non-treated } & \multicolumn{2}{|c|}{ Castrated } & \multicolumn{3}{|c|}{ Castrated + Es. } \\
\hline \multirow{2}{*}{\multicolumn{2}{|c|}{$\begin{array}{l}\text { No. of rats } \\
\text { Age (weeks) }\end{array}$}} & \multirow{2}{*}{\multicolumn{3}{|c|}{$\begin{array}{l}15 \\
69 \\
\end{array}$}} & \multirow{2}{*}{\multicolumn{2}{|c|}{$\begin{array}{r}9 \\
52 \\
\end{array}$}} & \multirow{2}{*}{\multicolumn{3}{|c|}{$\begin{array}{l}29 \\
75 \\
\end{array}$}} \\
\hline & & & & & & & & & \\
\hline Glu & $(\mathrm{mg} / \mathrm{d} \ell)$ & 395.4 & & 93.31 & 235.2 & \pm 26.54 & 164.4 & \pm & 19.79 \\
\hline GOT & (I. U. $/ \ell$ ) & 150.9 & \pm 1 & 113.70 & 48.1 & \pm 8.67 & 49.8 & \pm & 6.78 \\
\hline GPT & (I. U. $/ \ell$ ) & 132.4 & \pm & 91.67 & 25.8 & $\pm \quad 2.71$ & 29.9 & \pm & 6.32 \\
\hline ALP & (I. U./ $/ \ell$ ) & 540.9 & \pm 3 & 311.56 & 170.3 & \pm 14.94 & 70.1 & \pm & 55.70 \\
\hline $\mathrm{TG}$ & $(\mathrm{mg} / \mathrm{d} \ell)$ & 122.9 & \pm & 55.22 & 59.8 & \pm 19.52 & 62.3 & \pm & 27.10 \\
\hline TChol & $(\mathrm{mg} / \mathrm{d} \ell)$ & 86.6 & \pm & 28.00 & 85.7 & \pm 7.14 & 116.0 & \pm & 11.49 \\
\hline BUN & $(\mathrm{mg} / \mathrm{d} \ell)$ & 33.1 & \pm & 13.35 & 10.5 & \pm 0.74 & 12.4 & \pm & 1.10 \\
\hline $\mathrm{TP}$ & $(\mathrm{g} / \mathrm{d} \ell)$ & 5.6 & \pm & 0.30 & 6.8 & \pm 0.28 & 7.5 & \pm & 0.33 \\
\hline Creat & $(\mathrm{mg} / \mathrm{d} \ell)$ & 0.6 & \pm & 0.09 & 0.7 & \pm 0.06 & 0.6 & \pm & 0.04 \\
\hline Alb & $(\mathrm{g} / \mathrm{d} \ell)$ & 2.8 & \pm & 0.19 & 3.5 & \pm 0.08 & 3.8 & \pm & 0.19 \\
\hline $\mathrm{A} / \mathrm{G}$ & ratio & 1.03 & \pm & 0.17 & 1.09 & \pm 0.10 & 0.99 & \pm & 0.07 \\
\hline TBil & $(\mathrm{mg} / \mathrm{d} \ell)$ & 0.22 & \pm & 0.07 & 0.20 & \pm 0.03 & 0.22 & \pm & 0.04 \\
\hline $\mathrm{S}-\mathrm{Ca}$ & $(\mathrm{mEq} / \ell)$ & 4.74 & \pm & 0.21 & 5.20 & \pm 0.16 & 5.47 & \pm & 0.19 \\
\hline
\end{tabular}

Values represent "Mean \pm S.D.". $\quad$ Es. : Estradiol benzoate

Table 2. Effect of castration and estradiol benzoate on pancreatic lesions in male $\mathrm{WBN} / \mathrm{Kob}$ rats

\begin{tabular}{|c|c|c|}
\hline $\begin{array}{l}\text { No. of animals examined } \\
\text { Age (weeks) }\end{array}$ & $\begin{array}{c}\text { Castrated } \\
9 \\
52 \\
\end{array}$ & $\begin{array}{c}\text { Castrated }+ \text { Es } \\
29 \\
75\end{array}$ \\
\hline \multicolumn{3}{|c|}{ Atrophy of exocrine pancreas } \\
\hline- & 0 & 25 \\
\hline+ & 2 & 3 \\
\hline H & 7 & 1 \\
\hline \multicolumn{3}{|l|}{ Atrophy of islets } \\
\hline- & 0 & 29 \\
\hline+ & 1 & 0 \\
\hline H & 8 & 0 \\
\hline
\end{tabular}

- no lesion $\quad+$ : slight

Es. : Estradiol benzoate

群の平均血糖値は $164.4 \pm 19.79 \mathrm{mg} / \mathrm{dl}(102 \sim 196 \mathrm{mg} / \mathrm{dl})$

であり，ほぼ正常範囲内の值を示した。

その他の項目では無処置対照群において糖尿病性腎症 の影響と思われる BUN の高値, 糖尿病による脂質代謝 異常を反映したと思われるトリグリセライド值の上昇拉 よび GOT, GP T ならびに ALP の軽度な增加がみら れた。しかし，エストロジェン投与群ではこの様な変化 は認められなかった。

病理組織学的検査 : 精巣摘出群およびェストロジェン 投与群の膵荿病変の発現頻度を Table 2 に示した。

膵蔵病变のらち, 外分泌線組織の萎縮は精巣摘出群で は9/9例に認められ，そのうち 7 例の変化は中等度ない
し高度であった。これに対し，エストロジェン投与群で は外分泌線組織の萎縮は 1 例にも認められなかった。ま た，膵島の萎縮も精巣摘出群では9/9例に認められ，そ のらち8例では高度であったのに対し，ェストロジェン 投与群では同様な変化は 1 例にも認められなかかった。

これらの精巣摘出群に認められた脺臓病变の組織像 は, 無処置対照群之同様に膵島の萎縮・消失, 外分泌線 組織の広範な萎縮と脂肪組織による置換, 膵島およびそ の周囲領域の線維化, 間質における炎症細胞浸潤と一モ ジデリン沈着等から構成されていた。これに対して，ェ ストロジェン投与群の組織像では外分泌線組織および膵 島にはこれらの変化は認められなかった（Fig. 3 )。 


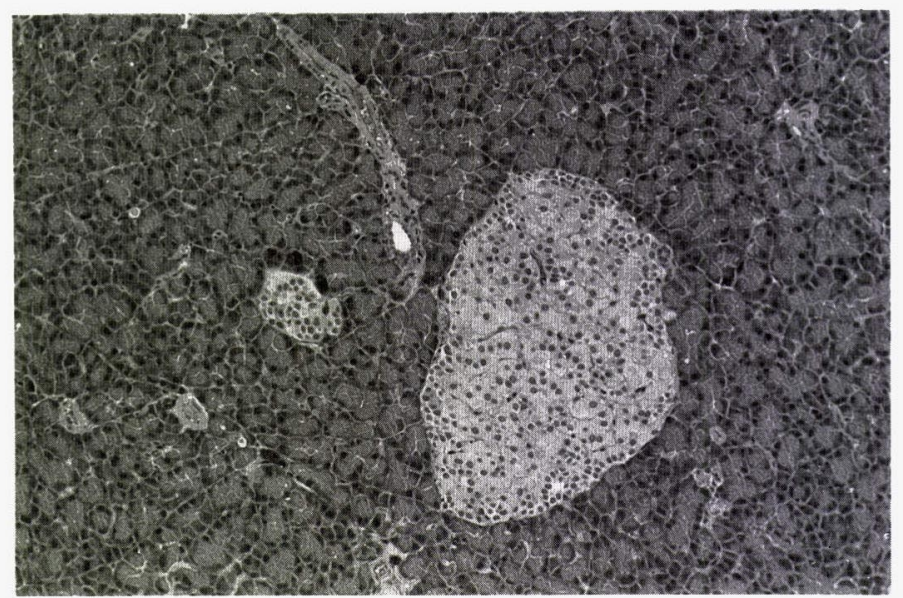

Fig. 3. Pancreas of castrated + Es. male WBN/Kob rat No lesion (H. E. $\times 100)$

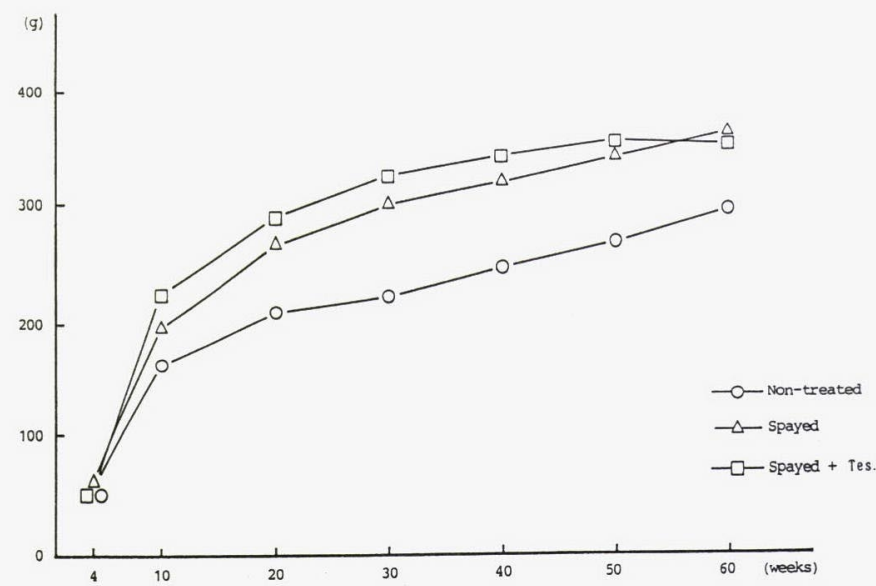

Fig. 4. Effect of spay and teststerone propionate on body weight changes in female WBN/Kob rats

2）雌ラット実験群

臨床症状 : 各群とも 12 力月を経ても一般状態に変化は 認められなかった。しかしながらテストステロン投与群 では55週龄時頃から尿糖陽性 (H〜H) 例が出現し, 75 週齢頃までの累積尿糖陽性率は63\%であった。

これに対して, 卵巣摘出群では72週龄時から尿糖陽性 （サ〜卅）例がみられ，88週齢までの累積尿糖陽性率は 32\%であった。

またこれら尿糖陽性例は尿糖出現と同時に多飲・多 尿を呈し, 徐々に削瘦した。また, このらち約半数は白
内障を併発していた。無処置対照群では88週齢まで尿糖 排泄例は認められなかった。

体重の推移：各群の体重の推移を Fig. 4 に示した。 テストステロン投与群の体重は10週齢から尿糖排泄例 が出現する55週路まで無処置対照群と比べて有意な高值 （約 25\%ないし 45\%の高値）で推移した。また，卵巣摘 出群の体重も10週柃から60週跲にかけて無処置対照群と 比べて有意な高值（約20\%ないし40\%の高值）で推移し た。

ブドウ糖負荷による耐糖能検査：30および60週踰にお 
Table 3. Effect of spay and teststerone propionate on serum biochemistry in female WBN/Kob rats

\begin{tabular}{|c|c|c|c|c|c|c|c|c|c|c|}
\hline \multicolumn{2}{|c|}{ Items $/$ Group } & \multicolumn{3}{|c|}{ Non-treated } & \multicolumn{3}{|c|}{ Spayed } & \multicolumn{3}{|c|}{ Spayed + Tes. } \\
\hline \multirow{2}{*}{\multicolumn{2}{|c|}{$\begin{array}{l}\text { No. of rats } \\
\text { Age (weeks) }\end{array}$}} & \multirow{2}{*}{\multicolumn{3}{|c|}{$\begin{array}{l}18 \\
88\end{array}$}} & \multirow{2}{*}{\multicolumn{3}{|c|}{$\begin{array}{l}37 \\
88\end{array}$}} & \multirow{2}{*}{\multicolumn{3}{|c|}{$\begin{array}{l}19 \\
75 \\
\end{array}$}} \\
\hline & & & & & & & & & & \\
\hline Glu & $(\mathrm{mg} / \mathrm{d} \ell)$ & 151.2 & & 26.33 & 234.3 & \pm & 64.26 & 329.9 & \pm & 165.62 \\
\hline GOT & (I. U./ $/ \ell$ ) & 47.6 & & 21.80 & 49.5 & \pm & 18.09 & 49.2 & \pm & 22.98 \\
\hline GPT & (I. U. $/ \ell$ ) & 17.6 & & 4.42 & 20.6 & \pm & 6.64 & 51.8 & \pm & 31.00 \\
\hline ALP & 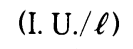 & 60.0 & & 10.00 & 125.4 & & 25.47 & 234.9 & \pm & 118.34 \\
\hline TG & $(\mathrm{mg} / \mathrm{d} \ell)$ & 80.1 & & 39.95 & 96.3 & \pm & 34.27 & 192.8 & \pm & 165.80 \\
\hline TChol & $(\mathrm{mg} / \mathrm{d} \ell)$ & 120.0 & & 23.43 & 101.4 & \pm & 10.94 & 130.4 & \pm & 62.91 \\
\hline BUN & $(\mathrm{mg} / \mathrm{d} \ell)$ & 16.6 & \pm & 3.07 & 16.4 & \pm & 5.97 & 23.5 & \pm & 20.05 \\
\hline $\mathrm{TP}$ & $(\mathrm{g} / \mathrm{d} \ell)$ & 7.3 & \pm & 0.60 & 6.8 & \pm & 0.34 & 6.3 & \pm & 0.50 \\
\hline Creat & $(\mathrm{mg} / \mathrm{d} \ell)$ & 0.7 & \pm & 0.05 & 0.6 & \pm & 0.11 & 0.7 & \pm & 0.45 \\
\hline Alb & $(\mathrm{g} / \mathrm{d} \ell)$ & 4.0 & \pm & 0.19 & 3.8 & \pm & 0.21 & 3.2 & \pm & 0.26 \\
\hline $\mathrm{A} / \mathrm{G}$ & ratio & 1.19 & \pm & 0.12 & 1.25 & \pm & 0.10 & 1.04 & \pm & 0.12 \\
\hline TBil & $(\mathrm{mg} / \mathrm{d} \ell)$ & 0.27 & \pm & 0.05 & 0.31 & \pm & 0.09 & 0.35 & \pm & 0.23 \\
\hline $\mathrm{S}-\mathrm{Ca}$ & $(\mathrm{mEq} / \ell)$ & 5.50 & \pm & 0.33 & 4.98 & \pm & 0.61 & 5.10 & \pm & 0.31 \\
\hline
\end{tabular}

Values represent "Mean \pm S.D.". Tes. : Teststerone propionate

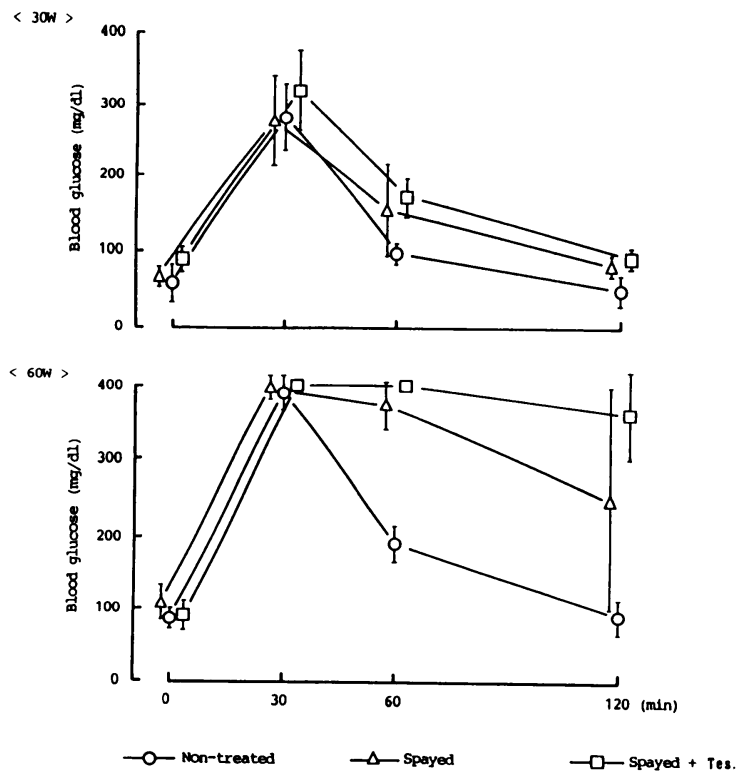

Fig. 5. Effect of spay and teststerone propionate on GTT levels in female WBN/Kob rats

ける各群の糖負荷後の血糖曲線を Fig. 5 に示した。 30週㱓では各群の血糖曲線はいずれも正常型を示し た。60週龄においてはテストステロン投与群の血糖曲線 は糖尿病型を示し, 卵巣摘出群においても耐糖能の低下
が明らかであったのに対し, 無処置対照群の血糖曲線は 依然として正常型であった。

血清生化学的検査 : 各群の血糖をはじめとする血清生 化学的検査を Table 3 に示した。

無処 置対照群の平均血糖値は $151.2 \pm 26.33 \mathrm{mg} / \mathrm{dl}$ （123 197mg/dl）であり，ほぼ正常範井内の值を示し た。これに対して, 卵巣摘出群およびテストステロン投

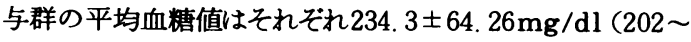
$421 \mathrm{mg} / \mathrm{dl})$ および $329.9 \pm 165.52 \mathrm{mg} / \mathrm{dl}$ (143〜660mg /dl）であり，明らかな高血糖を示した。

その他, テストステロン投与群では TG, ALP \& BUN 值が高値を示した。

病理組織学的検査 : 各群の脺荿病変の発現頻度を Table 4 に示した。

脺䑏病変のうち, 外分泌線組織の萎縮は卵巣摘出群お よびテストステロン投与群ではそれぞれ 28/37例および 15/19例に認められた。両群ともこのうちの約半数は中 等度ないし高度な変化を示したのに対し, 無処置対照群 の外分泌組織は2/19例で極軽度に萎縮しているにすぎな かった。また，腈島の萎縮も卵巣摘出群およびテストス テロン投与群ではそれぞれ35/37例および19/19例に認め られ，そのほとんどが高度な変化であったのに対し，無 処膡群では2/19例に認められたにすぎなかった。

これらの卵巣摘出群およびテストステロン投与群に認 められた膵荿病変の組織像は，脺島の萎縮・消失のほ か, 外分泌線組織の広範な萎縮と脂肪組織による置換, 
Table 4. Effect of spay and teststerone propionate on pancreatic lesions in female WBN/Kob rats

\begin{tabular}{|c|c|c|c|}
\hline $\begin{array}{l}\text { No. of animals examined } \\
\text { Age (weeks) }\end{array}$ & $\begin{array}{c}\text { Non-treated } \\
19 \\
88\end{array}$ & $\begin{array}{c}\text { Spayed } \\
37 \\
88\end{array}$ & $\begin{array}{c}\text { Spayed }+ \text { Tes. } \\
19 \\
75\end{array}$ \\
\hline \multicolumn{4}{|c|}{ Atrophy of exocrine pancreas } \\
\hline- & 17 & 9 & 4 \\
\hline+ & 1 & 10 & 6 \\
\hline H & 1 & 18 & 9 \\
\hline \multicolumn{4}{|l|}{ Atrophy of islets } \\
\hline- & 17 & 2 & 0 \\
\hline+ & 1 & 5 & 0 \\
\hline H & 1 & 30 & 19 \\
\hline
\end{tabular}

- : no lesion $\quad+$ : slight $\quad+$ : moderate-severe

Tes. : Teststerone propionate

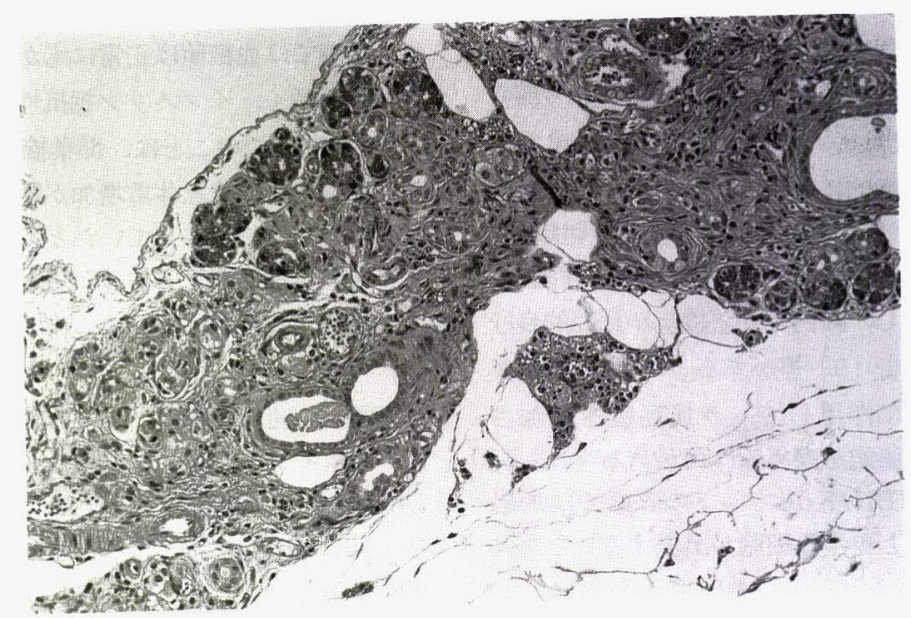

Fig. 6. Pancreas of spayed + Tes. female WBN/Kob rat Atrophy or disappearance of lslet tissue and atrophy of exocrine pancreatic tissue $($ H. E. $\times 100)$

膵島およびその周井領域の線維化, 間質における炎症 細胞の浸潤と一モデジリン沈着等から構成されていた (Fig. 6)。このような組織像はWBN/Kob の高血桾発 症ラットのそれと同質であった。これに対して, 無処置 対照群の膵藏では外分泌組織の萎縮を示した 2 例を除い て外分泌組織および萃島のいずれにも明らかな組織学的 変化は認められなかった。

\section{考察}

雄だけに自然発症するWBN/Kob ラットにおける高
血糖発症と膵臓病変が, 雌ラットの性腺を摘出した場合 にも，発現することから本系統ラットの自然発症糖尿病 の遺伝的な発症因子が雄だけでなく, 雌にも存在するこ とが明らかにされた [7]。今回の実験では雌雄ラットの 性腺摘出とそれに加えて雌珄および雄性ホルモン（エス トロジェン，テストステロン）を投与し，本系統ラット の糖尿病態に対する両ホルモンの影響について調べた。 無処置雄ラットでは30週路で既に尿糖陽性例の発現を 伴って耐糖能が低下し, 精巣摘出群では60週龄で耐糖能 が低下したのに対し，テストステロン投与群ではこの様 な変化を示すものは 1 例もいなかった。したがって, 精 
巣摘出によってWBN/Kob ラットの糖尿病態の発症は 遅延するのに加えて, 精巣摘出十エストロジェン投与で は60週龄まで完全に発病が抑制されることが明らかにな った。糖尿病症状と膵臓の組織学的变化が密接な関連を 持つことは既に知られており [15]，特に膵島および $\beta$ 細胞の減数と糖尿病状態が概ね並行して進行することが 確認されている。精巣摘出群の膵葴では無処置雄ラット とほぼ同質の炎症性変化が認められたが, その程度は無 処置雄ラットに比べ稍軽度であり, 逆に正常組織は無処 置雄ラットに比較してょり良好に保たれていた。一方, エストロジェン投与群の脺病変は無処置倠ラットのそれ とほぼ同様であり, 殆ど榶尿病性の変化を欠いていた。 これは, 雌性ホルモンが糖尿発症に抑制的に作用してい るとした先の報告の推論を支持しているのに加えて, 雄 性ホルモン除外も同様に糖尿病発症を遅延させる効果を 持つことを示唆していた。

エストロジェンの作用についてはラットの膵切除後に これを投与すると糖尿病の発症が抑制されたといら報告 [4]，イ邓の膵広範囲切除後，エストロジェンが残存膵 の再生を形態的にも機能的にも促進させるといら報告 [5]，イヌの膵管結紮腺維化膵に脺管再建兼脺切除後， エストロジェン投与群で糖尿病の発症が著明に抑制さ れ, 脺線維化率が減少し, 䐗内外分泌機能が比較的良好 に維持されたとする報告 [9] 等がある。これらの結果 はェストロジェンが脺に作用して，ラ氏島数を增加さ せ，そのインスリン分泌能を高める作用がある $[1,2,6]$ ことを推測させる。WBN/Kob ラットの膵臓では加龄 とともに島細胞が減少し再生島細胞が出現することが知 られている [15]。エストロジェンの作用としては，こ れら再生島細胞の增加とともに現時点まで充分に解明さ れていない本系統ラットの膵島 $\beta$ 細胞破壊作用を防御す る機構に関与するのかも知れない。WBN/Kob ラット の糖尿病の発症に対するェストロジェンの抑制作用に ついては既に仲間らによっても確認されている $[12,13]$ が，その詳細なメカニズムについては不明である。今回 の実験結果もこれらの報告とよく一致していたが，副堅 皮質ホルモンをはじめとする他のステロイド系ホルモン との相互作用あるいは捛抗作用等については, ホルモン 定量も実施されておらず，充分な解明には至らなかっ た。一方，倠実験において無処置ラットは高龄に至るま で異常が認められなかったのに対し，テストステロン投 与群で55週龄頃から, 卵巣摘出群ではそれより約 4 ヶ月 遅れて尿糖陽性例が出現した。糖負荷試験でもそれらに 先立ち，耐糖能の低下が認められた。膵病变においても 卵巣摘出群およびテストステロン投与群のそれは無処置雄
ラットとほぼ同質の変化を示した。また, 無処置雄ラッ トに屡々認められるトリグリセライドの高値も合わせて 認められ，テストステロン投与群は無処置雄ラットの糖 尿病態のそれとほぼ合致していると考えられた。 Nonaka らは, KK 系マウスの糖尿病発現に雄性ホルモンが重要 な役割を果たしていることを報告しているが [10]，本 系統ラットにおいてもテストステロンの糖尿病態の発症 促進効果が示唆された。

各群の体重に関して，尿糖発症が抑制されたエストロ ジェン投与群では無処置雄ラットの体重にほほ近似して いた。一方, 卵巣摘出およびテストステロン投与群の体 重は, 無処置雌ラットのそれに比べ有意な高値で推移 し, 精巣摘出群の体重に近かった。これらの群では60週 齢時に耐糖能の低下が見られたが，その時期と体重增加 の程度とは概ね合致していると考えられた。ところで, 糖尿の発症に関与する因子の一つに肥満があげられてお り, 肥満では血糖値は正常にもかかわらず, 血中インス リン值が高く、インスリン抵抗性があることが知られて いる [14]。このことは, 卵巣摘出あるいはテストステ ロン投与群の顕著な体重增加が糖尿病態の進展に二次的 なものとして，関与していたとも考えられた。テストス テロンがもたらすその他の作用としては，エストロジェ ンの場合と同様, 本実験においては明らかに出来なかっ た。

結局, 今回の成績はラットの勝切除後, 様々なステロ イドホルモンを投与した結果エストロジェン作用をるつ ものは糖尿病の頻度を减少させたが，アンドロジェン様 のものは増進させたとする Lewis らの報告 [8]とも一 致する。

いずれにしても，WBN/Kobラットの糖尿病発現には 雌性ホルモンが抑制的に作用していること，また，雄性 ホルモンがその発症を促進していることは確認し得た。

\section{要約}

WBN/Kob ラットの糖尿病発症に及ぼす性ホルモン の影響を検討するため性腺摘出に加え，倠雄に性ホルモ ンを投与し, 尿糖の発症, 体重推移, 耐糖能ならびに病 理組織学的所見を無処置対照群のそれと比較した。その 結果, 雌無処置群および雄エストロジェン投与群では異 常はなかったが, 雄の無処固群では約30週龄, 精巣摘出 群で52週㱓，雌のテストステロン投与群で55週龄，卵巣 摘出群で72週龄より尿糖排泄がみられはじめた。また， それに先立ち、これらの群では耐糖能の低下が認められ た。雄の体重では対照群に比べて精巣摘出, エストロジ 
ェン投与群の順に顕著な低值を示し, 雌では対照群に対 し, 卵巣摘出, テストステロン投与群の順に顕著な高値 を示した。膵蔵の組織学的検査では, 精单摘出群, 卵巣 摘出群およびテストステロン投与群で基本的に WBN/ Kob 雄ラットと同質の変化（外分泌腺組織の萎縮およ び脺島の萎縮・消失）が認められたが，雌の対照群およ び雄のエストロジェン投与群ではこれらの変化はなかっ た。 WBN/Kob ラットの尿糖排泄を伴ら高血糖発症に は雌性ホルモンが抑制的に作用していること，また，雄 性ホルモンがその発症を促進していることが示唆された。

\section{文献}

［1］朝倉徹夫（1986）。去勢成熟雌ラットの膵 Langerhans 島細胞におよぼす estrogen, progesteronの作用に関す る組織学的研究. 三重医学, 30, 93-99.

[2] Costrini, N. V. and Kalkhoff, R. K., (1971). Relative effects of pregnancy, estradiol and progesterone on plasma insulin and pancreatic islet insulin secretion. J. Clinical Investigation, 50, 992-999.

[3] 藤原敏彦・牛山 泉・吉岡慎二・䏱越大能・土谷 稔 奈良間 功 (1987). 新しい自然発症糖尿病モデルラット (WBN/Kob) の糖尿病態の解析. 糖尿病動物 第 1 巻, pp. 150-157, 後藤由夫編, 医薬ジャーナル社, 東京.

[4] Houssay, B. A. (1951). Action of sex hormones on experimental diabetes. Br. Med J. Sept. 1., 505510 .

[5] 林 唐 (1983). 膵広範囲切除後の残存脺の再生と Estrogenの効果. 日粹研プロシーディングス，13，4849.

[6] 小塚良允 (1982). 妊娠時の耐糖能に関寸る研究：ラッ ト灌流膵を用いた HCG, HPL, Estrogen, progesterone などの胎盤産生 Hormone の Insulin 分泌能におよぼす 検討. 三重医学, 26,7-15.
[7] 昆 弘志.三枝 雅.土谷 稔. 奈良間 功 (1988). WBN/Kob ラットの糖尿発症に及ぼす性腺摘出の影響. 実験動物， 37， 429-435.

[8] Lewis, J. T., Foglia, V. G., and Rodriguez, R. R. (1950). The effects of steroids on the incidence of diabetes in rats after subtotal pancreatectomy. Endocrinology, 46, 111-121.

［9］水本龍二・渡辺泰和・山本敏雄・世古口務 (1985)。脺 管結禁織維化膵切除後の残存膵に対する Estrogen の効 果，難治性膵疾患調查研究班報告書，195-203．

[10] Nonaka, T., Higuchi, N., Arai, T., and Oki, Y. (1988). Effect of castration androgen on glycosuria appearance in the diabetic $\mathrm{KK}$ mice induce by monosodium glutamate administration. Jpn J. Vet. Sci, 50, 1121-1123.

[11）仲間一雅 - 七戸和博 - 秋元敏雄 - 清水真澄 - 深沢晶子 石崎正通・ 小林和雄・戸部満寿夫 (1987). WBN/Kob ラットの糖尿病症状および膵・堅の組織学的変化につい て。糖尿病動物 第 1 巻, PP. 158-161, 後藤由夫編, 医 薬ジャーナル, 東京.

[12] 仲間一雅・秋元敏雄・清水真澄 - 七戸和博 - 戸部满寿夫 (1988).WBN/Kob 雄ラットの自然発症糖尿病に対する Estrogen の発症抑止効果について. 糖尿病動物 第 2 巻, PP. 130-136, 後藤由夫糄, 医楽ジャーナル, 東京.

[13］仲間一雅・秋元敏雄・大橋和史・金 重輝 - 原 浩子 户部満寿夫 (1989). WBN/Kobラットの自然発症膵疾患 について一膵病変発現・性差についての一考一, 桾尿病 動物 第 3 巻, PP. 154-162, 後藤由夫編, 医薬ジャーナ ル, 東京.

［14］佐々木英夫（1991）。糖尿病.内科学, pp. 1488-1499, 上田英夫・竹内重五郎・杉本恒明監修, 朝倉書店, 東京.

[15] Tsuchitani, M., Saegusa, T., Narama, I., Nishikawa, T., and Gonda, T. (1985). A new diabetic strain of rat (WBN/Kob). Lab. Anim, 19, 200-207.

[16] Tsuchitani, M., Kuroda, J., Nagatani, M., Miura, K., Katoh, T., Saegusa, T., Narama, I., and Itakura, C. (1990). Glycogen accumulation in the renal tubular cells of spontaneously occurring diabetic WBN/Kob rats. J. Comp. Path, 102, 179-190. 